\title{
Editorial
}

Journal of Innate

Immunity
J Innate Immun 2017;9:1-2

DOI: $10.1159 / 000453127$
Published online: December 7, 2016

\section{Intracellular Clearance by Nobel Laureates}

We were pleased to learn that the 2016 Nobel Prize in Physiology or Medicine has been awarded to Yoshinori Ohsumi for his discoveries of the mechanisms involved in autophagy. The terms autophagism, autophagia, and autophagy were first used at the beginning of the 20th century, applied in different contexts including tumor wound-healing [1], phagocytosis of microphages [2], and traumatized rats [3]. However, the word autophagy as a term to describe the clearance of damaged organelles, removing cytosolic components and maintaining bioenergetic homeostasis, was introduced in the early 1960 s by another Nobel laureate, Christian de Duve [4]. He received the Nobel Prize together with George E. Palade in 1974 for discoveries concerning the structural and functional organization of the cell. Three decades later, the first published autophagy paper by Yoshinori Ohsumi and colleagues [5] described yeast cells lacking vacuolar proteases, showing extensive accumulation of autophagic bodies under various adverse environmental conditions.

Notably, more than 180 outstanding and groundbreaking papers have followed, underlining the importance of these findings. Today, we know that autophagy is an essential cytosolic clearance mechanism that not only helps to maintain normal cell homeostasis, but is also a critical regulator of the intracellular immune system [6]. The Journal of Innate Immunity has recently issued a couple of articles dealing with this area of research [7-9]. In this volume, there is a paper by Katarina Nurmi et al. [10] on a study reporting that hemin and cobalt protoporphyrin can inhibit NLRP3 inflammasome activation by enhancing autophagy.

\section{KARGER}

(C) 2016 S. Karger AG, Basel
Pulmonary complications often involve a modulation of innate immune responses [11-19], and many studies have shown that surfactant proteins play a critical role in these processes [review in 20]. In this issue, Sylvia Ujma et al. [21] present an excellent review article, describing surfactant proteins A and B as being expressed also in many other parts of the body, such as the reproductive, urinary, and gastrointestinal tracts, where they have important innate immune functions and combat a wide range of microbial infections.

Apart from this review, there are contributions from Jonathan Leffler et al. [22] and Bethany M. Biron et al. [23], analyzing the degradation of neutrophil extracellular traps (NETs) in Shiga toxin-associated hemolytic uremic syndrome, and showing that the chemical inhibition of protein arginine deiminases and, consequently, that of histone citrullination and NET formation, leads to increased survival against septic insult. Along with other NET articles published in the Journal of Innate Immunity [24-26], these studies emphasize the importance of neutrophils and extracellular traps in the early immune response to an invading pathogen. Together with the other contributions in the first 2017 issue, this collection of articles covers a number of essential scientific problems within the field of innate immunity that should be of great interest to our readers.

Heiko Herwald, Lund Arne Egesten, Lund 


\section{References}

1 Podwyssotzki W: Autolysis and autophagism in endotheliomae and sarcomae, as a basis principle for the elaboration of a method of healing unoperated tumors. Beitr Pathol Anat 1905;38:449-455.

2 Toumanoff K: The phagocytosis of microphages by macrophages (autophagia) in inflammation. C R Seances Soc Biol Fil 1925;93: 1281-1282.

3 Nash CB: Autophagia in rats traumatized during inanition. Science 1940;91:342-343.

4 Klionsky DJ: Autophagy revisited: a conversation with Christian de Duve. Autophagy 2008;4:740-743.

5 Takeshige K, Baba M, Tsuboi S, Noda T, Ohsumi Y: Autophagy in yeast demonstrated with proteinase-deficient mutants and conditions for its induction. J Cell Biol 1992;119: 301-311.

6 Deretic V: Autophagy as an innate immunity paradigm: expanding the scope and repertoire of pattern recognition receptors. Curr Opin Immunol 2012;24:21-31.

7 Golbach LA, Scheer MH, Cuppen JJ, Savelkoul H, Verburg-van Kemenade BM: Lowfrequency electromagnetic field exposure enhances extracellular trap formation by human neutrophils through the NADPH pathway. J Innate Immun 2015;7:459-465.

8 Stranks AJ, Hansen AL, Panse I, Mortensen M, Ferguson DJ, Puleston DJ, Shenderov K, Watson AS, Veldhoen M, Phadwal K, Cerundolo V, Simon AK: Autophagy controls acquisition of aging features in macrophages. J Innate Immun 2015;7:375-391.

9 Khan N, Pahari S, Vidyarthi A, Aqdas M, Agrewala JN: NOD-2 and TLR-4 signaling reinforces the efficacy of dendritic cells and reduces the dose of TB drugs against Mycobacterium tuberculosis. J Innate Immun 2016;8: 228-242.

10 Nurmi K, Kareinen I, Virkanen J, Rajamäki K, Kouri VP, Vaali K, Levonen AL, Fyhrquist N, Matikainen S, Kovanen PT, Eklund KK: Hemin and cobalt protoporphyrin inhibit NLRP3 inflammasome activation by enhancing autophagy: a novel mechanism of inflammasome regulation. J Innate Immun 2016; 9:65-82.
11 Abdillahi SM, Bober M, Nordin S, Hallgren $\mathrm{O}$, Baumgarten $\mathrm{M}$, Erjefält J, WestergrenThorsson G, Bjermer L, Riesbeck K, Egesten A, Morgelin M: Collagen VI is upregulated in COPD and serves both as an adhesive target and a bactericidal barrier for Moraxella catarrhalis. J Innate Immun 2015;7:506-517.

12 Sawant KV, Xu R, Cox R, Hawkins H, Sbrana E, Kolli D, Garofalo RP, Rajarathnam K: Chemokine CXCL1-mediated neutrophil trafficking in the lung: role of CXCR2 activation. J Innate Immun 2015;7:647-658.

13 Benedyk M, Mydel PM, Delaleu N, Plaza K, Gawron K, Milewska A, Maresz K, Koziel J, Pyrc K, Potempa J: Gingipains: critical factors in the development of aspiration pneumonia caused by Porphyromonas gingivalis. J Innate Immun 2016;8:185-198.

14 Bruscia EM, Bonfield TL: Cystic fibrosis lung immunity: the role of the macrophage. J Innate Immun 2016;8:550-563.

15 Carevic M, Öz H, Fuchs K, Laval J, Schroth C, Frey N, Hector A, Bilich T, Haug M, Schmidt A, Autenrieth SE, Bucher K, Beer-Hammer S, Gaggar A, Kneilling M, Benarafa C, Gao JL, Murphy PM, Schwarz S, Moepps B, Hartl D: CXCR1 regulates pulmonary anti-Pseudomonas host defense. J Innate Immun 2016;8 362-373.

16 Choudhary S, Boldogh I, Brasier AR: Insideout signaling pathways from nuclear reactive oxygen species control pulmonary innate immunity. J Innate Immun 2016;8:143-155.

17 García-Laorden MI, Stroo I, Blok DC, Florquin S, Medema JP, de Vos AF, van der Poll $\mathrm{T}$ : Granzymes A and B regulate the local inflammatory response during Klebsiella pneumoniae pneumonia. J Innate Immun 2016;8: 258-268.

18 Vencken SF, Greene CM: Toll-like receptors in cystic fibrosis: impact of dysfunctional microRNA on innate immune responses in the cystic fibrosis lung. J Innate Immun 2016;8: 541-549.
19 Yoon CM, Nam M, Oh YM, Dela Cruz CS Kang MJ: Mitochondrial regulation of inflammasome activation in chronic obstructive pulmonary disease. J Innate Immun 2016; 8:121-128.

20 Nayak A, Dodagatta-Marri E, Tsolaki AG, Kishore U: An insight into the diverse roles of surfactant proteins, SP-A and SP-D in innate and adaptive immunity. Front Immunol 2012;3:131.

21 Ujma S, Horsnell WG, Katz AA, Clark HW, Schäfer G: Non-pulmonary immune functions of surfactant proteins A and D. J Innate Immun 2016;9:3-11.

22 Leffler J, Prohászka Z, Mikes B, Sinkovits G, Ciacma K, Farkas P, Réti M, Kelen K, Reusz GS, Szabó AJ, Martin M, Blom AM: Decreased neutrophil extracellular trap degradation in Shiga toxin-associated haemolytic uraemic syndrome. J Innate Immun 2016; 9:12-21.

23 Biron BM, Chung CS, O’Brien XM, Chen Y, Reichner JS, Ayala A: Cl-amidine prevents histone 3 citrullination and neutrophil extracellular trap formation, and improves survival in a murine sepsis model. J Innate Immun 2016;9:22-32.

24 Ramos MV, Mejias MP, Sabbione F, Fernandez-Brando RJ, Santiago AP, Amaral MM, Exeni R, Trevani AS, Palermo MS: Induction of neutrophil extracellular traps in Shiga toxin-associated hemolytic uremic syndrome. J Innate Immun 2016;8:400-411.

25 Braem SG, Rooijakkers SH, van Kessel KP, de Cock H, Wosten HA, van Strijp JA, Haas PJ: Effective neutrophil phagocytosis of Aspergillus fumigatus is mediated by classical pathway complement activation. J Innate Immun 2015;7:364-374.

26 Carlsen ED, Jie Z, Liang Y, Henard CA, Hay C, Sun J, de Matos Guedes H, Soong L: Interactions between neutrophils and Leishmania braziliensis amastigotes facilitate cell activation and parasite clearance. J Innate Immun 2015;7:354-363. 